\title{
Empowerment On Climate Change: How Community Based Organizations Serving In Growing participation from society
}

\author{
Friska Indria Nora Harahap $^{1 *}$, Mahfuzi Irwan ${ }^{2}$ \\ ${ }^{1}$ Department of Non Formal Education, Indonesia University of Education \\ ${ }^{2}$ Department of Community Education, Medan State University \\ * Korespondensi Penulis. Email: hrp.frischa@gmail.com
}

\begin{abstract}
Climate change is not something scary, dangerous. Urgent, exceptional and most importantly is that climate change was not known when it happened. And the thing to do is not frightened by the climate change, but it must be to explain to the people and groups that climate change is inevitable and things to do is to minimize the impact of climate change. One of them is by not cutting down trees carelessly, can manage waste and preserve family environment such as that done by the community Pangerwangi village, Lembang, West Java. The village which has been awarded as the climate village for being able to survive and adapt to climate change .. Because the essence of Kampung climate is how the community to survive and adapt to the climate because it is people who have to adjust to the climate. And achievements that have been achieved not in spite of community participation and community-based organizations.
\end{abstract}

Keywords: Climate change, Community Empowerment, Community Based Organizations

\section{PENDAHULUAN}

Pendidikan merupakan unsur penting dalam suatu negara. Kesejahteraan manusia ada kaitannya dengan Pendidikan. Pendidikan di Indonesia mempunyai berbagai peran dalam kaitannya dengan kehidupan. Pendidikan yang dinilai sebagai aspek mendasar dalam usaha membelajarkan manusia ke arah lebih baik. Pembangunan pada setiap negara ada kaitannya dengan pendidikan. Pendidikan dinilai sebagai nilai investasi dalam peradaban suatu negara. Negara yang maju juga dapat dilihat dari segi pendidikan.

Pendidikan luar sekolah adalah aktifitas pendidikan yang terjadi diluar sistem persekolahan, salah satu wujudnya adalah pendidikan di masyarakat. Sebagaimana disebutkan oleh Hiryanto (2008) bahwa pendidikan luar sekolah atau pendidikan nonformal adalah usaha memberdayakan manusia, memampukan manusia, mengembangkan talenta talenta yang ada pada diri manusia agar dengan kemampuan/potensi yang dimilikinya dapat dikembangkan melalui pendidikan /pembelajaran.

Salah satu isu nasional dalam rangka pembangunan yang berdasarkan laporan United Nation tahun 2015 bahwa pasca agenda pembangunan 2015, yang dikenal dengan istilah Tujuan Pembangunan Berkelanjutan (SDGs), diharapkan dapat menanggulangi berbagai masalah, termasuk menghapuskan kemiskinan dan kelaparan, memajukan kesehatan dan pendidikan, membangun kota-kota secara berkelanjutan, memerangi perubahan iklim serta melindungi samudera dan hutan. Untuk dapat mengimplementasikan hal tersebut dapat dilakukan melalui Pemberdayaan Masyarakat yang mengacu pada proses pendidikan nonformal.

Pembangunan yang mengedepankan pemberdayaan masyarakat adalah adanya perbaikan kualitas hidup yang lebih baik dalam rangka menghadapi permasalahan yang dihadapi. Korten (1993), menyatakan 
Journal of Millennial Community, 1 (1), March 2019

Friska Indria Nora Harahap, Mahfuzi Irwan

bahwa pembangunan adalah proses di mana anggota-anggota suatu masyarakat meningkatkan kapasitas peroranan dan kelompok mereka untuk menghasilkan perbaikan-perbaikan yang berkelanjutan dan merata dalam kualitas hidup sesuai dengan aspirasi mereka sendiri. Dalam konteks penguatan kelompok, diperlukan perubahan structural terhadap kelembagaan local menuju peningkatan taraf hidup, produktifitas, kreatifitas, pengetahuan dan keterampilan maupun kapasitas kelembagaan agar senantiasa survival dan mampu beradaptasi dengan perubahan sosial yang melingkipinya. Seperti yang dikatakan oleh Chillag As Chillag et al. (2002) point out, communitybased organizations are well positioned to deliver such services "because they understand their local communities and are connected to the groups they serve" Transformasi yang demikian, sedapat mungkin dilakukan secara mandiri dan atas kebutuhan masyarakat sendiri. seperti yang dilakukan oleh Kalaupun ada intervensi dari pihak lain hanya bersifat memfasilitasi.

Permasalahan yang terjadi Saat ini kelompok-kelompok khususnya di daerah pedesaan tidak berjalan dengan baik. Secara kuantitas memang terdapat banyak kelompok yang telah dibentuk. Tetapi secara kualitas yang dikatakan mandiri belum begitu terjadi dengan baik. Hal tersebut mengapa terjadi menurut Syahyuti (dalam Parma, 2014) karena disebabkan oleh beberapa faktor, diantaranya adalah (1) kelompok tani pada umumnya dibentuk berdasarkan kepentingan teknis untuk memudahkan pengkoordinasian apabila ada kegiatan atau program pemerintah, sehingga lebih bersifat orientasi program, dan kurang menjamin kemandirian kelompok dan keberlanjutan kelompok, (2) partisipasi dan kekompakan anggota kelompok dalam kegiatan kelompok relatif rendah.ini tercermin dari tingkat kehadiran anggota dalam pertemuan kelompok rendah, (3) pengelolaan kegiatan produktif anggota kelompok bersifat individu. Kelompok sebagai forum kegiatan bersama belum mampu menjadi wadah pemersatu kegiatan anggota dan pengikat kebutuhan anggota secara bersama, sehingga kegiatan produktif individu lebih menonjol, (4) pembentukan dan pengembangan kelembagaan tidak menggunakan basis sosial capital setempat dengan prinsip keotonomian dan pemberdayaan, (5) pembentukan dan pengembangan kelembagaan berdasarkan konsep cetak biru (blue print approach) yang seragam. Introduksi kelembagaan dari luar kurang memperhatikan struktur dan jaringan kelembagaan lokal yang telah ada, serta kekhasan ekonomi,sosial, dan politik yang berjalan, (6) pembentukan dan pengembangan kelembagaan berdasarkan pendekatan yang top down, menyebabkan tidak tumbuhnya partisipasi masyarakat, (7) kelembagaan-kelembagaan yang dibangun terbatas hanya untuk memperkuat ikatan horizontal, bukan ikatan vertikal, dan (8) pengembangan kelembagaan selalu menggunakan jalur structural, dan lemah dari pengembangan aspek kulturalnya.

Pemberdayaan masyarakat melalui penguatan kelompok lokal masyarakat dirasa penting sebagai upaya memandirikan masyarakat itu sendiri. Dengan adanya kelompok di masyarakat akan mudah mempengaruhi masyarakat untuk dapat terlibat program. Oleh karena itu Makalah ini akan menganalisis "Pemberdayaan Masyarakat Pada Isu Perubahan Iklim Melalui Penguatan Kelompok Lokal Masyarakat". Hal yang dibahas mengenai pemberdayaan yang seperti apa dalam rangka penguatan kelompok tersebut.

\section{METODE}

Penelitian ini menggunakan pendekatan kualitatif. Pendekatan kualitatif menghasilkan data deskriptif berupa kata-kata tertulis dan lisan dari orang -orang dan perilaku yang diamati. Cresswell (2016: 4) mengemukakan bahwa pendekatan kualitatif bertujuan untuk mengeksplorasi dan memahami yang oleh sejumlah individu atau sekelompok orang yang dianggap berasal dari masalah sosial atau kemanusiaan. Pendapat tersebut sejalan dengan tujuan penelitian untuk menemukan dan menganalisis secara detail 
pemberdayaan masyarakat melalui penguatan kelompok lokal masyarakat. Dan dalam penelitian kualitaif tidak menggunakan istilah populasi tetapi narasumber, partisipan atau informan. Menurut Bungin (2008 : 76) informan penelitian adalah subyek yang memahami informasi obyek penelitian sebagai pelaku maupun orang lain yang memahami obyek penelitian. Berdasarkan hal tersebut sangatlah jelas bahwa yang menjadi sumber data atau subyek penelitian dalam penelitian ini adalah pihak yang terlibat langsung, memiliki pengetahuan, dapat mengemukakan, menjelaskan, menyatakan, mendemonstrasikan, dan memperlihatkan berbagai kegiatan berkenaan dengan fokus penelitian yang berhubungan dengan pemberdayaan masyarakat pada isu perubahan iklim melalui penguatan kelompok lokal masyarakat. Penelitian ini dilakukan di Desa Pangerwangi Kecamatan Lembang Kabupaten Bandung Barat. Teknik pengumpulan data dalam penelitian ini menggunakan interview, observasi dan study literatur. Interview dilakukan ketua kelompok yang berhubungan dengan upaya mengatasi dampak perubahan iklim karena dian karena dianggap mempunyai kapasitas keorisinilan informasi. Observasi yang dilakukan bertujuan untuk melihat secara langsung kondisi masyarakat yang telah mendapatkan imbas dari pemberdayaan masyarakat pada isu perubahan iklim melalui penguatan kelompok lokal. Dan study literatur dalam penelitian ini mengkaji dan menganisis laporan dan kajian-kajian literature lain yang memiliki keterkaitan dengan focus penelitian.

\section{HASIL DAN PEMBAHASAN}

Berbagai kejadian terkait dengan kondisi iklim yang tidak menentu seperti, banjir, kekeringan, longsor, dll yang berdampak kepada kerusakan, kerugian bahkan korban jiwa. Dan kondisi tersebut bukan saja menjadi perhatian pemerintah atau mereka yang bergerak di bidang pelestarian lingkungan tetapi menjadi tanggung jawab bersama. Upaya bersama dalam mitigasi dan adaptasi bencana sangat diharapkan juga dilakukan oleh masyarakat pada tingkat lokal, untuk membantu pemerintahan menuju cakupan yang lebih besar. Seperti yang dilakukan oleh masyarakat kampung Panger wangi yang telah melakukan pengelolaan lingkungan dan telah terbukti berhasil dengan diperolehnya penghargaan sebagai Kampung Iklim Tahun 2015 dari Kementerian Lingkungan Hidup. Pengelolaan lingkungan yang dilakukan oleh masyarakat Panger Wangi berupa pengolahan dan daur ulang sampah yang dilakukan oleh ibu-ibu. Selain daur ulang pengolahan lingkungan yang dilakukan berupa upaya peningkatan ekonomi seperti pembuatan pupuk kompos untuk perkebunan sendiri dan ada juga yang diperjualbelikan. Selain itu setiap masyarakat yang mempunyai kebun wajib menanan pohon di sekitar kebun dengan tujuan untuk menahan lingsor. Selain itu masyarakat Panger Wangi juga sudah menyadari akan pentingnya akan kebutuhan air dan menyimpan air dengan adanya setiap rumah mempunyai talang air untuk menampung air jika sedang musim hujan dan juga mempunyai bak penampungan air hujan untuk persediaan. Dikarenakan lokasi dari Kampung Pangerwangi ini didaerah dataran tinggi jadi sangat sulit untuk mendapatkan air jika harus menggali sumur, dan juga hutan masyarakat yang sudah banyak beralih fungsi jadi villa sehingga sumber-sumber air pun semakin sedikit. Untuk itu, masyarakat mempunyai inisiatif menanami jurangjurang dengan bambu dimana bambu dipercaya selain dapat menahan longsor dan sangat bagus dalam hal menahan air hujan. Aksi masyarakat tersebut tidak akan terjadi tanpa dimotori oleh lembaga yang menaungi aksi masyarakat tersebut yang bernama Lembaga Keswadayaan Masyarakat (LKM) Rukun Wangi. Lembaga Keswadayaan Masyarakat (LKM) Rukun Wangi dibentuk sebagai implementasi dari Program Nasional Pemberdayaan Masyarakat Mandiri Perkotaan sebagai institusi yang mengakar kemasyarakat, yang akan mampu menjadi motor penggerak masyarakat untuk 
Journal of Millennial Community, 1 (1), March 2019

Friska Indria Nora Harahap, Mahfuzi Irwan

menanggulangi kemiskinan secara berkelanjutan.

Kelompok Sebagai Sasaran Pemberdayaan Masyarakat

Kelompok dalam masyarakat memiliki peranan untuk mempengaruhi individu untuk terlibat dalam suatu kegiatan pembangunan. Unsur keterlibatan masyarakat menjadi hal yang sangat mempengaruhi dalam rangka pembangunan yang menggunakan asas pemberdayaan masyarakat. Keberadaan kelompok ini akan sangat membantu dalam hal kegiatan pemberdayaan masyarakat tersebut. Kelompok masyarakat juga dianggap sebagai salah satu potensi lokal yang dimiliki oleh masyarakat itu sendiri. Untuk dapat memberdayakan masyarakat, kelompok juga harus memiliki kemampuan yang memadai untuk dapat diterima sebagai sebuah pelopor perubahan sosial masyarakat itu sendiri.

Ada beberapa pengertian dari kelompok oleh beberapa ahli diantaranya adalah oleh Katzenbach and Smith (Mickan dan Rodgers, 2000) menjelaskan bahwa sebuah kelompok adalah sejumlah kecil orang dengan keterampilan yang saling melengkapi yang berkomitmen untuk tujuan yang sama, tujuan kinerja, dan pendekatan yang mereka menahan diri saling akuntabel. Selain itu, komunikasi yang teratur, koordinasi, peran khas, tugas saling bergantung dan norma-norma bersama adalah fitur penting

Selain itu Smith (Abarca dkk, 2000) mendefinisikan sebuah kelompok sebagai sekumpulan kecil orang yang berkomitmen untuk sesuatu yang lebih besar dari diri mereka sendiri. Untuk pembahasan ini , kelompok didefinisikan sebagai sekumpulan orang secara kolektif mengemudi menuju tujuan bersama, memanfaatkan dan menghormati keterampilan dan pengetahuan semua individu. Pendapat lain seperti Campbell (Gil-White, 2001) berpendapat bahwa kumpulan individu dianggap sebagai kelompok untuk tingkat bahwa perkumpulan ini memiliki karakteristik dari suatu identitas.
Kelompok sebagai bagian dari masyarakat terbentuk melalui kesamaan tujuan berdasarkan norma yang ada di masyarakat. Mengenai hal tersebut normanorma itu sendiri tumbuh dalam masyarakat memiliki tingkatan kekuatan mengikat tersendiri. Seperti yang dipaparkan Soekanto (2002) dalam Sosiologi sebagai Pengantar bahwa untuk dapat membedakan kekuatan mengikat norma-norma tersebut dikenal adanya empat pengertian, yaitu: a. Cara (usage) b. Kebiasaan (folksway) c. Tata kelakuan (mores), dan d. Adat istiadat (custom).

Hal tersebut selalu menjadi bagian dimasyarakat terlebih di kehidupan kelompoknya tidak jauh dari norma-norma yang berlaku tersebut. Norma di masyarakat menjadi pedoman dalam melaksanakan kehidupan dan kuat mengakar kuat di masyarakat sebagai bagian dari kehidupan.

Sebagai bentuk kesatuan yang utuh dalam masyarakat kelompok memiliki peran penting. Hal tersebut dikarenakan Menurut Sukmana (2010) Setiap kelompok mempunyai kondisi potensi lokal yang unik yang dapat membantu atau menghambat pengembangan ekonominya. Potensi tersebut menjadi hal yang penting untuk menunjukkan peran kelompok di masyaraakat. Adanya kelompok bisa jadi sebagai penyemangat yang baik bagi individu-individu yang tergabung di dalamnya. Selain itu kelompok di masyarakat juga sangat membantu dalam hal memfasilitasi keterlibatan masyarakat dalam perencanaan dan pelaksanaan program pemberdayaan yang ada di masyarakat. Seperti yang dikatakan oleh Wilson et al, (2012) mengatakan bahwa Furthermore, successful involvement of community-based organizations (and the Public) in decision-making has been shown to increase The likelihood that policies will be appropriate, acceptable And effective. Namun keberadaan kelompok juga dapat berlaku sebagai penghambat adanya pembaharuan-pembaharuan yang terjadi. Maka oleh karena itu perlu adanya penguatan kelompok dalam mengatasi kemungkinan terburuk. Sehingga adanya 
Journal of Millennial Community, 1 (1), March 2019

Friska Indria Nora Harahap, Mahfuzi Irwan

pemberdayaan masyarakat seutuhnya akan mudah di dapat jika kelompok di dalam masyarakat berdaya juga.

Penguatan Kelompok dalam Rangka Pemberdayaan Masyarakat

Pemberdayaan kelompok menurut United Nations (1983) dalam Tohjiwa \& Suparman dapat disimpulkan paling tidak ada 6 unsur dalam pemberdayaan komunitas yang sangat penting, yaitu : (1) sekelompok orang (a group of people), (2) dalam sebuah komunitas (in a community), (3) mencapai keputusan bersama (reaching a decision), (4) untuk merencanakan dan melaksanakan proses aksi sosial (to initiate a social action process / planned intervention), (5) untuk merubah (to change), (6) situasi ekonomi, sosial, budaya, atau lingkungan mereka (their economic, social, cultural, or environmental situation). Di dalam Pemberdayaan mencakup tiga dimensi yang meliputi kompetensi kerakyatan, kemampuan sosiopolitik, dan kompetensi partisipatif (Suharto, 2005) yaitu :

1. Sebuah proses pembangunan yang bermula dari pertumbuhan individual yang kemudian berkembang menjadi sebuah perubahan sosial yang lebih besar

2. Sebuah keadaan psikologis yang ditandai oleh rasa percaya diri, berguna dan mampu mengendalikan diri dan orang lain.

3. Pembebasan yang dihasilkan dari sebuah gerakan sosial, yang dimulai dari pendidikan dan politisasi orangorang lemah dan kemudian melibatkan upaya-upaya kolektif dari orang-orang lemah

Pemberdayaan masyarakat salah satunya mencakup adanya gerakan sosial dan politisasi orang-orang lemah. Untuk mendapatkan hasil yang seperti itu maka dapat dilakukan melalui pendekatan kelompok. Penguatan kelompok menjadi salah satu upaya untuk meningkatkan kompetensi kelompok tersebut, sehingga dengan adanya kelompok yang kuat maka akan dapat menjalankan tugasnya tersebut. Kartasasmita (1996) menyampaikan bahwa proses pemberdayaan dapat dilakukan melalui tiga proses yaitu: a) menciptakan suasana atau iklim yang memungkinkan potensi masyarakat berkembang (enabling). b) memperkuat potensi atau daya yang dimiliki oleh masyarakat (empowering), c) memberdayakan juga mengandung arti melindungi. Adapun salah satu tujuan yang ingin dicapai dari pemberdayaan kelompok tani adalah untuk membantu kelompok tani menjadi mandiri.

Pemberdayaan kelompok pada hakekatnya merupakan suatu proses perubahan sosial yang sengaja, terarah, dan direncanakan. Adapun Unsur-unsur yang terkandung dalam suatu perubahan sosial dirumuskan oleh Kotler (1978: 29-33) disebutkan ada lima unsur diantaranya adalah:

1. Cause (sebab), yaitu upaya atau tujuan sosial yang dipercaya oleh pelaku perubahan dapat memberikan jawaban pada problem sosial.

2. Change agency (agen perubahan), yaitu organisasi yang misi utamanya memajukan upaya perubahan sosial.

3. Change target (sasaran perubahan), yaitu individu atau kelompok sosial yang ditunjuk sebagai sasaran upaya perubahan.

4. Channel (saluran), yaitu media untuk menyampaikan pengaruh dan respon dari setiap pelaku perubahan ke sasaran perubahan. - Change strategy (strategi perubahan), yaitu teknik utama mempengaruhi yang diterapkan oleh pelaku perubahan untuk menimbulkan dampak pada sasaran perubahan.

Pemberdayaan berarti mempersiapkan masyarakat desa dan kelompok mereka untuk memperkuat diri dalam berbagai hal, mulai dari soal kelembagaan, kepemimpinan, sosial ekonomi, dan politik dengan menggunakan basis kebudayaan mereka sendiri. Syahyuti (2007) menyebutkan ada dua prinsip dasar 
yang seyogyanya dianut di dalam proses pemberdayaan kelompok. Pertama, adalah menciptakan ruang atau peluang bagi kelompok tani dan anggotanya untuk mengembangkan dirinya secara mandiri. Kedua, mengupayakan agar kelompok dan anggotanya memiliki kemampuan untuk memanfaatkan ruang atau peluang yang tercipta tersebut.

Selain itu menurut Ermayanti (2014) Selama proses pelaksanaan program pemberdayaan masyarakat, masyarakat yang berbasis kelompok dikembangkan melalui beberapa aspek diantarannya kelembagaan secara sosial dan ekonomi yang berisi nilai- nilai tradisional dan kearifan lokal sehingga setiap program pemerintah yang masuk ke wilayahnya dapat ditampung melalui kelompok yang telah terbentuk tersebut.

Keberadaan kelompok bisa jadi sebagai sumber kekuatan bagi masyarakat. kelompok dipandang sebagai penghimpun kekuatan tersebut untuk dapat menggerakkan partisipasi masyarakat. Selain itu adanya kelompok diharapkan dapat berperan sebagai penghubung dengan beberapa program-program pemerintah, terlebih program yang mengarah kepada perbaikan kualitas kehidupan masyarakat. Kelompok ini sering dijumpai seperti di kelompok tani, kelompok wanita tani, kelompok nelayan, dll.

Alasan mengapa harus kelompok dijawab oleh Berdasarkan hasil penelitian Goldsmith dan Blustain (dalam Sandyatma dan Hariadi, 2012 ) mengambil lokasi penelitian di Jamaika bahwa anggota masyarakat termasuk petani di dalamnya akan tergerak berpartisipasi jika salah satunya adalah partisipasi dilakukan melalui organisasi atau kelompok yang sudah dikenal atau yang sudah ada di tengahtengah masyarakat. Selain itu Husodo (2006) mengemukakan bahwa partisipasi akan efektif apabila dilaksanakan secara kolektif dalam wadah kelompok. Sehingga hal tersebut adanya kelompok yang kuat akan mempengaruhi tingkat kepercayaan masyarakat pada kelompok itu sendiri.

$$
\text { Kelompok lokal bentukan }
$$

masyarakat menurut Andriani (2010) menjadi wahana berhimpunnya anggota masyarakat, di mana warga dapat berinteraksi menjalin kerjasama untuk dapat menyatukan kepentingan bersama di tingkat komunitas. Hubungan organisasi lokal bersifat horizontal, diperkuat lagi oleh hubungan-hubungan antar anggota dalam organisasi lokal terlepas dari pengaruh birokrasi pemerintah, sangat tepat sebagai pintu masuk bagi pengembangan masyarakat.

Penguatan kelompok sebagai bagian dari pemberdayaan masyarakat sangatlah penting untuk dapat menghimpun kekuatan masyarakat seluruhnya sehingga masyarakat dapat berpartisipasi aktif terhadap program pemberdayaan masyarakat itu sendiri. Menurut Yunita, dkk (2014) Kelompok dalam melaksanakan perannya memerlukan pengorganisasian dengan ketrampilan khusus untuk memberikan dorongan dan bantuan secara sistematis. Secara ideal, pengembangan kapasitas kelompok dilakukan melalui pendekatan self-help (membantu diri sendiri). Pendekatan yang berorientasi proses, membantu masyarakat dalam belajar bagaimana mengatasi masalah mereka sendiri. Adapun hal yang mencakup penguatan kapasitas terasebut perlu adanya komunikasi sebagai bentuk interaksi yang intensif dari komponenkomponen kapasitas kelompok. Dari hal tersebut, pengembangan kapasitas kelompok fokus kepada empat strategi pengembangan, antara lain disampaikan oleh Chaskin (dalam Andini, 2012) diantaranya adalah sebagai berikut:

1. Leadership Development

2. Organizational Development

3. Community Organizing

4. Interorganizational Collaboration

Dari keempat fokus pengembangan komunitas tersebut ada satu hal yang sangat penting dalam penguatan kapasitas kelompok yaitu community organizing, hal tersebut adalah kemampuan kelompok mengorganisir masyarakat agar mau untuk berpartisipasi. Community organizing merupakan salah satu cara yang dibutuhkan untuk meningkatkan kapasitas sosial dari suatu komunitas. Pengorganisasian 
Journal of Millennial Community, 1 (1), March 2019

Friska Indria Nora Harahap, Mahfuzi Irwan

komunitas menawarkan transformasi sosial sebagai berikut (Sinclair, 2006):

1. Memotivasi masyarakat untuk mengambil tindakan yang selaras dengan nilai-nilai dan kepercayaan mereka.

2. Menghubungkan komunitas dengan hasrat dan mengakui adanya generatif kekuatan amarah.

3. Membawa individu-individu yang terisolasi yang berjuang dalam kondisi yang sama ke dalam sebuah komunitas bersama dengan yang lainnya.

Lebih lanjut oleh Stall dan Stoecker (dalam Andini, 2013), pengorganisasian komunitas merupakan sebuah proses pembangunan komunitas yang dapat dimobilisasi. Hal ini meliputi membangun jaringan orang-orang, mengidentifikasi citacita bersama, dan siapa yang dapat terlibat dalam tindakan/aksi sosial untuk mencapai cita-cita bersama tersebut. Pengorganisasian komunitas mengacu kepada keseluruhan proses pengorganisasian hubungan, pengidentifikasian isu, mobilisasi orang untuk isu tersebut, serta mengurus dan mempertahankan organisasi. Pengorganisasian komunitas juga merupakan suatu proses membangun kekuatan yang melibatkan orang-orang dalam mendefinisikan persoalan-persoalan suatu komunitas, mendefinisikan persoalan yang ingin diselesaikan, solusi yang diangkat, dan metode yang digunakan untuk melaksanakan solusi persoalan komunitas tersebut.

Proses pengorganisasian komunitas ini dapat meningkatkan modal sosial baik bagi individual dengan cara meningkatkan dan memperkuat relasi di antara sesama dan dengan membangun kepercayaan dan mengakui kepentingan bersama (Chaskin, dalam Andini 2013). Dalam hal ini kemampuan membangun pola jaringan yang baik dituntut sebagai satu modal sosial yang penting.

Aspek Penting dalam Penguatan Kelompok untuk Pemberdayaan Masyarakat
Dalam rangka penguatan kelompok itu sendiri terdapat dua pokok yang mesti dilakukan yang sudah ada di masyarakat yang menjadi modal untuk pembangunan. Caventa dan Valderama dalam Mulyana, y (2013) bahwa keberhasilan pembangunan diukur dari seberapa besar masyarakat mampu mendayagunakan modal yang mereka miliki yang secara kategoris terdiri dari:

1. Modal Manusia (human resources), yang meliputi jumlah penduduk, skala rumah tangga, kondisi pendidikan dan keahlian serta kondisi kesehatan warga. Selain itu Huseini (1999) menjelaskan bahwa modal manusia merupakan refleksi dari pendidikan, pengalaman, intuisi dan keahlian. Kaitannya dengan modal manusia ini adalah keterkaitannya adalah peningkatan kapasitas individu yang didapat sebagai anggota dalam kelompok masyarakat tersebut. Pandangan lain diutarakan oleh Widjayanti (2011) modal manusia (human capital) adalah suatu aset yang berhubungan dengan intelektualitas dan kondisi seseorang yang diperoleh melalui pendidikan formal dan nonformal yang didukung oleh kesehatan jasmani dan rohani yang prima dan kemampuan melakukan hubungan/interaksi antarsesama secara baik, menguntungkan, dan berkelanjutan.

2. Modal Social (Social Captal Resourches), yakni jaringan kekerabatan dan budaya, serta keanggotaan dalam kelompok, rasa saling percaya, lembaga kemasyarakatan, pranata sosial dan tradisi yang mendukung, serta akses kepada kelembagaan sosial yang sifatnya lebih luas. Widjayanti (2011) menyebutkan bahwa modal sosial adalah suatu norma atau nilai yang telah dipahami bersama oleh masyarakat yang dapat memperkuat jaringan sosial/kerja yang positif, terjalinnya kerjasama yang saling 
Journal of Millennial Community, 1 (1), March 2019

Friska Indria Nora Harahap, Mahfuzi Irwan

menguntungkan, menumbuhkan kepedulian dan solidaritas yang tinggi dan dapat mendorong tingkat kepercayaan antara sesama dalam rangka tercapainya tujuan bersama.

Lebih lanjut mengenai modal sosial tersebut Ermayanti (2014) mengungkapkan bahwa Strategi sosial dilakukan dengan jalan memanfaatkan ikatan-ikatan sosial yang ada di perdesaan baik berupa lembaga kesejahteraan lokal, hubungan produksi hingga jejaring sosial berbasis kekerabatan atau pertemanan. Rasa percaya antar warga (trust) sangat tinggi. Rasa percaya antar warga yang tinggi ini menyebabkan pola hutang-piutang antar rumah tangga dapat berjalan dengan baik. Pentingnya kepercayaan pribadi dalam mempertahankan modal sosial. Modal sosial merupakan salah satu andalan bagi masyarakat, khususnya di masyarakat pedesaan. Ikatan kekerabatan, pertetanggaan dan pertemanan yang kuat memberikan ruang yang cukup bagi rumah tangga miskin untuk mengakses modal sosial ini.

Hal tersebut sesuai jika dikaitkan dengan dengan pernyataan Blakey (dalam Sukmana, 2010) yang menyebutkan bahwa dalam rangka pengembangan ekonomi masyarakat terletak pada titik sentralnya yang mengarah pada kebijakan endogenous development menggunakan potensi sumberdaya manusia, institusional dan fisik setempat sehingga orientasi ini mengarahkan kepada focus dalam proses pembangunan untuk menciptakan lapangan kerja baru dan merangsang pertumbuhan kegiatan ekonomi.

Berdasarkan hal tersebut jelas sekali pemberdayaan masyarakat dapat dilakukan dengan merujuk pada apa yang dimiliki oleh masyarakat yaitu sumberdaya manusia sebagai modal manusia dan institusional yang lebih mengarah kepada pembangunan kelompok masyarakat, hal tersebut dikaitkan dengan modal sosial masyarakat. Modal Manusia mempengaruhi individu dalam bertindak sedangkan modial sosial memberikan pengaruh sebagai satu kekuatan bersama.

Perubahan iklim telah dicatat sebagai sebuah tantangan yang harus dihadapi oleh ummat manusia. Meskipun demikian, manusia di seluruh dunia telah gagal untuk mengembangkan respon yang efektif dan signifikan terhadap perubahan iklim tersebut bahkan penelitian yang signifikan di masa lalu membuktikan bahwa orang-orang lebih memilih untuk tidak mengambil tindakan terhadap perubahan iklim, walaupun isu perubahan iklim menjadi perhatian banyak pihak seperti, pihak Nasional, Lokal, Regional dan bahkan dunia Internasional seperti PBB genjargenjar melakukan program pembangunan berkelanjutan seperti mengurangi gas emisi tahun 2015 yang lalu. Berbagai kejadian terkait dengan kondisi iklim yang tidak menentu seperti banjir, kekeringan, longsor, gelombang tinggi, dan peningkatan muka air laut semakin sering terjadi dengan intensitas yang semakin meningkat, sehingga menimbulkan korban jiwa serta kerugian ekonomi dan ekologi. Kondisi tersebut perlu disikapi tidak hanya oleh pihak Pemerintah atau orang-orang yang bergerak di bidang kelestarian lingkungan hidup, tetapi untuk seluruh ummat manusia. Untuk memperkuat aksi nyata dalam menghadapi dampak perubahan iklim, di tingkat local juga diharapkan dapat berkontribusi terhadap upaya mitigasi untuk mengurangi emisi Gas Rumah Kaca serta upaya adaptasi untuk meningkatkan kapasitas seluruh pihak dalam menghadapi dampak perubahan iklim.

Desa Pangerwangi adalah salah satu desa yang sudah mendapat penghargaan Program Kampung Iklim (Proklim) yaitu sebuah penghargaan untuk kampung yang sudah dinilai oleh Kementerian Lingkungan Hidup sudah melakukan upaya mitigasi dan adaptasi terhadap perubahan iklim (Kementerian Lingkungan Hidup). Dalam mewujudkan Proklim di desa Pangerwangi bukanlah hal yang mudah bagi organisasi, karena mengingat bahwa setiap ada perubahan pasti ada yang pro dan kontra. 
Journal of Millennial Community, 1 (1), March 2019

Friska Indria Nora Harahap, Mahfuzi Irwan

Dalam melakukan perubahan,mengubah kebiasaan, dan menerapkan hal-hal baru bagi masyarakat bukanlah hal yang mudah, semua itu membutuhkan proses dan strategi tertentu.

Program Kampung Iklim di Desa pangerwangi tercipta melalui organisasi yang berbasis masyarakat yang ada di desa pangerwangi. Strategi yang digunakan oleh organisasi ini untuk menciptakan Kampung Iklim adalah dengan menggunakan strategi pemberdayaan bottom up, yaitu pemberdayaan yang dimulai dari bawah. Karena dalam hal membuat bank sampah sendiri yang telah dikelola oleh masyarakat sampai sekarang awal mulanya berasal dari kegiatan tim organisasi yang memungut sampah setiap harinya dari tiap-tiap RW, kemudian bergabung dengan program posyandu yang diadakan sekali dalam sebulan dan pemberian makanan tambahan (PMT) bagi ibu-ibu yang memiliki balita. Kumpulan ibu-ibu pada Posyandu yang menjadi sasaran pertama dalam program bank sampah, yaitu semua ibu-ibu yang ada di posyandu dibagikan (kantongan plastic) dan cara mengenali dan memilah sampah organic dan anorganik. Tidak hanya itu, selain memberikan penukaran untuk sampah yang di kumpulkan oleh masyarakat seperti penukaran sembako, di bank sampah juga membuat simpan pinjam untuk lebih menarik minat masyarakat untuk ikut serta.

Selain bank sampah, program lain yang ada di Desa Pangerwangi adalah adanya rumah kompos Panger Wangi. Yang hampir semua masyarakat menjadi anggota, dan dapat membuat pupuk sendiri baik untuk lahan pertanian pribadi maupun untuk di jual. Dan formula pupuk kompos Desa Pangerwangi yang diciptakan oleh organisasi sendiri sudah di distribusikan ke Pemerintah Kota Bandung untuk di konsumsi secara massal yang dampaknya menambah penghasilan masyarakat.

Bentuk lain dari program Kampung iklim yang ada di Desa Panger Wangi tidak hanya sebatas pembuatan bank sampah, rumah kompos panger wangi tetapi masih banyak yang lainnya, seperti pembuatan talang yang bertujuan untuk menampung air hujan yang langsung dialirkan ke bak penyimpan air masyarakat karena diketahui desa tersebut adalah dataran tinggi yang susah untuk mendapatkan air. Pembuatan taman sayuran untuk setiap rumah untuk mengurangi biaya belanja rumah tangga. Dan untuk menjaga bagian hutan dan perkebunan, diakanannya sosialisasi dan proses penyadaran kepada masyarakat untuk menanam 1 pohon untuk setiap kebun sayuran, yang berfungsi untuk mencengah longsor, dan membuat kolamkolam penampungan yang dilapisi terpal untuk mengurangi penggunaan air tanah diwaktu kemarau tiba.

\section{SIMPULAN}

Perubahan iklim adalah bukan sesuatu hal yang menakutkan, berbahaya. Mendesak, luar biasa dan yang terpenting adalah bahwa perubahan iklim itu tidak diketahui kapan terjadi. Dan hal yang dapat dilakukan adalah tidak merasa takut dengan perubahan iklim tersebut, tetapi harus lebih kepada menjelaskan kepada masyarakat dan kelompok bahwa perubahan iklim itu bisa diperkecil dengan salah satunya dengan mengurangi emisi gas rumah kaca ke tingkat yang akan membatasi perubahan iklim, menjaga lingkungan sekitar dan tidak merusak. Karena esensi dari Kampung iklim adalah bagaimana cara masyarakat untuk dapat bertahan dan beradaptasi dengan iklim karena manusialah yang harus menyesuaikan dengan iklim.

\section{DAFTAR PUSTAKA}

Abarca, J. dkk. (2000). Introductory Engineering Design: A Project Based Approach. Amerika: Regents Of Colorado University

Ermayanti. (2014). Studi Pengembangan Kelembagaan Berdasarkan Kultur Masyarakat Lokal Pada Kelompok Nelayan. Jurnal Antropologi: Isu-Isu Sosial Budaya. 16 (2), p. 149-165

Gil-White, Fransisco J. 2001. Are Ethnic Groups Biological "Species" To The Human Brain?: Essentialism In Our Cognition of Some Social Categories. Current Antrophology. 42 (04), p. 515-553 
Journal of Millennial Community, 1 (1), March 2019

Friska Indria Nora Harahap, Mahfuzi Irwan

Hiryanto. (2008). Pemberdayaan Masyarakat Melalui Pendidikan Nonformal. Disampaikan dalam Lokakarya Pemberdayaan Masyarakat dalam Pendidikan Luar Sekolah tanggal 22 November 2008, di Badan Perencanaan Pembangunan Daerah (Bappeda) Kabupaten Bantul

Husodo, S. 2006. Partisipasi Petani dalam Kegiatan DAFEP di Kabupaten Bantul. Jurnal Ilmu-Ilmu Pertanian, 2 (1). p. $18-27$

Kotler, P. (1972).Creating Social Change. New York: Hold Rinehart and Winston Inc

Mickan, S \& Rodgers, S. (2000). Characteristic Of Effective Teams: $A$
Literatur Review. Australian Health Review. 23 (03). p. 201-208

Sinclair, Zack \& Lisa Russ. 2006. Organization Development for Social Change: An Integrated Approach to Community Transformation. Zack Sinclair and Movement Strategy Center.

Soekanto, S. (2002). Sosiologi Suatu Pengantar. Jakarta: PT. Raja Grafindo Persada

Syahyuti. (2007). Kebijakan Pengembangan Gabungan Kelompok Tani (Gapoktan) Sebagai Kelembagaan Ekonomi di Pedesaan. Bogor: Pusat Analisis Sosial Ekonomi dan Kebijakan Pertanian 